\title{
Hydro-Chemistry of Gokyo Valley, Sagarmatha (Everest) National Park, Nepal
}

\author{
Rajendra Bhandari ${ }^{*}$, Subodh Sharma1, Juerg Merz², Robin Garton² \\ ${ }^{1}$ Department of Environmental Science and Engineering, Kathmandu University, Dhulikhel, Nepal \\ ${ }^{2}$ The Glacier Trust, Wiltshire, UK \\ Email: *rajendra.bhandari@ku.edu.np
}

Received 1 September 2015; accepted 27 November 2015; published 30 November 2015

Copyright (C) 2015 by authors and Scientific Research Publishing Inc.

This work is licensed under the Creative Commons Attribution International License (CC BY).

http://creativecommons.org/licenses/by/4.0/

c) (i) Open Access

\section{Abstract}

This research work records the baseline inventory of selected ions in running waters of Gokyo Valley, Nepal and tries to establish relationship of these ions' concentration with elevation gradient. Among these selected hydro-chemical parameters, the average concentration of $\mathrm{Ca}^{2+}, \mathbf{M g}^{2+}$, $\mathrm{SO}_{4}^{2-}$ and total silica were determined to be $3.25( \pm 2.02), 0.64( \pm 0.47), 207.2( \pm 423.01)$ and 0.36 $( \pm 0.17) \mathrm{mg} / \mathrm{L}$ respectively. Concentration of these parameters was low compared to earlier studies except $\mathrm{SO}_{4}^{2-}$ that could be justified too since the sampling was performed only once in drier period with low atmospheric input of acid protons required for weathering process. Moreover, Pearson Product-moment Correlation Coefficients ( $r$ ) for elevation gradient and concentration of $\mathrm{Ca}^{2+}, \mathrm{Mg}^{2+}, \mathrm{SO}_{4}^{2-}$ and total silica were determined to be $+0.350,+0.145,+0.101$ and -0.275 respectively. Such weak relationship between these parameters and elevation gradient suggests that the concentration of these ions is related to weathering phenomena, glacier and watershed characteristics and snow cover dynamics in Gokyo Valley.

\section{Keywords}

Gokyo Valley, Himalayan Streams, Hydrochemistry, Sagarmatha National Park

\section{Introduction}

Limnological research in the Himalayas has been carried out since the beginning of the 20th century by Sars, 1903 and Hutchinson, 1932 (As cited in [1]). Present decades have seen more detailed approach with greater focus on morphometric, physiochemical and biological features, primary production and trophic status and par-

*Corresponding author.

How to cite this paper: Bhandari, R., Sharma, S., Merz, J. and Garton, R. (2015) Hydro-Chemistry of Gokyo Valley, Sagarmatha (Everest) National Park, Nepal. Journal of Geoscience and Environment Protection, 3, 74-81.

http://dx.doi.org/10.4236/gep.2015.39007 
ticular emphasis for fish production [1] indicating very low concentration of dissolved minerals at altitude above $4000 \mathrm{~m}$ a.s.l. Nevertheless, the studies in the higher Himalayas of Nepal are scanty irrespective to the studies done in high altitude water bodies in Kashmir and Sikkim in the northwest Himalayas [1]. The study carried out by [2] in 24 lakes at altitude between 4500 and $5600 \mathrm{~m}$ a.s.l. in the Mount Everest area provides the first data on morphometry, temperature, chemistry and biology. Concerning the overall lake studies performed in Nepal, more than 163 research studies have been reported including master's thesis from 1969 to 2010 [3].

Lakes in Gokyo regions are studied systematically by assigning their names as Lake Cadstre Numbers (LCN) and the results indicate that these lakes are oligotrophic and alkaline and have low ionic content [1]. More recently, various limnological studies have been carried out in Gokyo region specially focusing on lakes [4]. The studies concerning physical-chemical including heavy metals, diatom and macroinvertebrate assemblages have also been carried out [4] [5].

The impact on water chemistry due to anthropogenic pollution from the industrial and agricultural sources has concerned environmentalists and scientists for past decades [6]. However, due to their remoteness high altitude lakes are less often affected by local sources of pollution. But their catchments receive deposition of pollutants due to long distance atmospheric transport [7]. Moreover, the chemistry of running waters draining the high mountain areas of Asia is largely unknown nevertheless; some studies conclude that the degree of pollution of these rivers increases with the distance from the high mountain first order streams and that pollution is increasing through time [6]. Geologically different catchments differ in both the release rates of elements to streams and lakes, and the relative proportion that are released. Yet, for the major ions at least, the relative proportion does not greatly differ in well-watered portion of the temperate, arctic and sub-tropical zones. The most common ion sequences as equivalent weight according to [8] are as follows:

$$
\begin{gathered}
\mathrm{Ca}^{2+}>\mathrm{Mg}^{2+}>\mathrm{Na}^{+}>\mathrm{K}^{+} \\
\mathrm{HCO}_{3}^{-}>\mathrm{SO}_{4}^{2-}>\mathrm{Cl}^{-}
\end{gathered}
$$

In this study, two cations $\left(\mathrm{Ca}^{2+}, \mathrm{Mg}^{2+}\right)$, sulphate and total silica are taken and their concentrations (mg/L) have been identified and plotted against elevation if there exists any relationship between these ions with elevation gradient.

\section{Materials and Methods}

\subsection{Study Area}

Gokyo Valley is situated in Sagarmatha National Park, one of the World Heritage Sites and is a designated Ramsar Site. It is located within $27^{\circ} 52^{\prime} \mathrm{N}$ to $28^{\circ} 05^{\prime} \mathrm{N}$ and $86^{\circ} 40^{\prime} \mathrm{E}$ to $86^{\circ} 43^{\prime} \mathrm{E}$. Total population of Khumjung VDC is 1912 with 913 males and 999 females, and has 551 households [9]. For the sampling of water for hydrochemistry, area from Phortse Thanga (3570 m asl) to Gokyo Lake Six (5125 m a.s.l) has been taken as shown in Figure 1. Several first order streams that are directly fed to Dudh Koshi River have been sampled. The sampling of water was done in the third week of May, 2013.

\subsection{Sampling and Analysis}

20 sampling stations were selected systematically and numbered from 1 to 20 as shown in Figure 2. Water samples for the analysis of calcium ion, magnesium ion, sulphate ion and total silica were analyzed in Aquatic Ecology Center, Kathmandu University. For the determination of calcium and magnesium ion concentration determination, Atomic Absorption Spectrophotometer (Thermo electron corporation; Model; M5MK2AA system), was used. Similarly for the determination of sulphate ion concentration and total silica concentration, Turbidimetric Spectrophotometric and Molybdosilicate Spectrophotometric (Model: Thermo Spectronic GRNESYS 10 UV) methods were used respectively. The guideline provided by APHA, AWWA and WEF (1998) [10] was strictly followed for the concentration determination of mentioned parameters. Microsoft Office Excel-2007 was used for the processing and analysis of data. This software was also used to construct Trend Graphs and to compute Pearson Product-moment Correlation Coefficient for selected parameters under study.

\section{Results and Discussion}

One time sampling for two cations $\left(\mathrm{Ca}^{2+}\right.$ and $\left.\mathrm{Mg}^{2+}\right)$, total silica and sulphate was done in 3rd week of May, 2013 


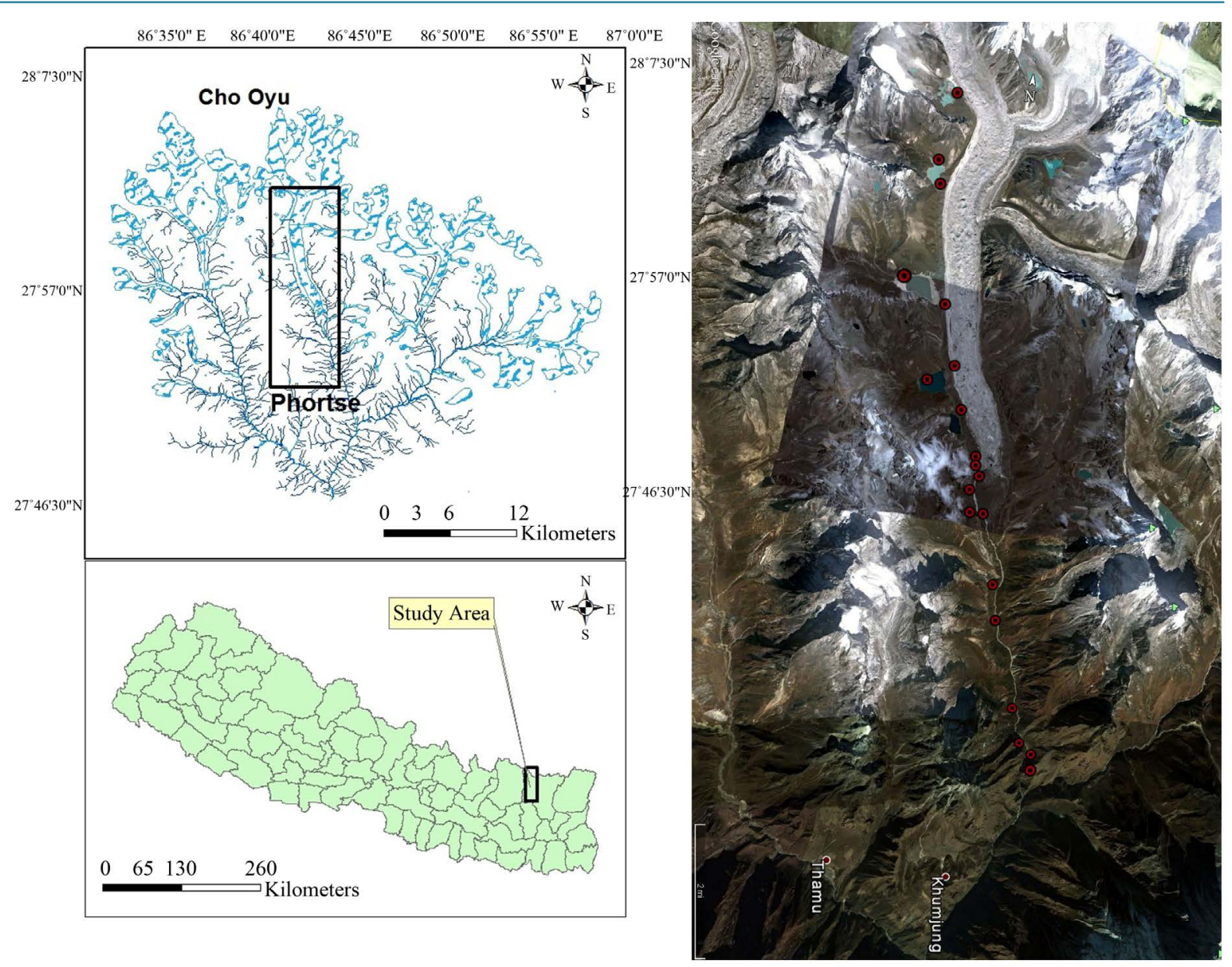

Figure 1. Study area.

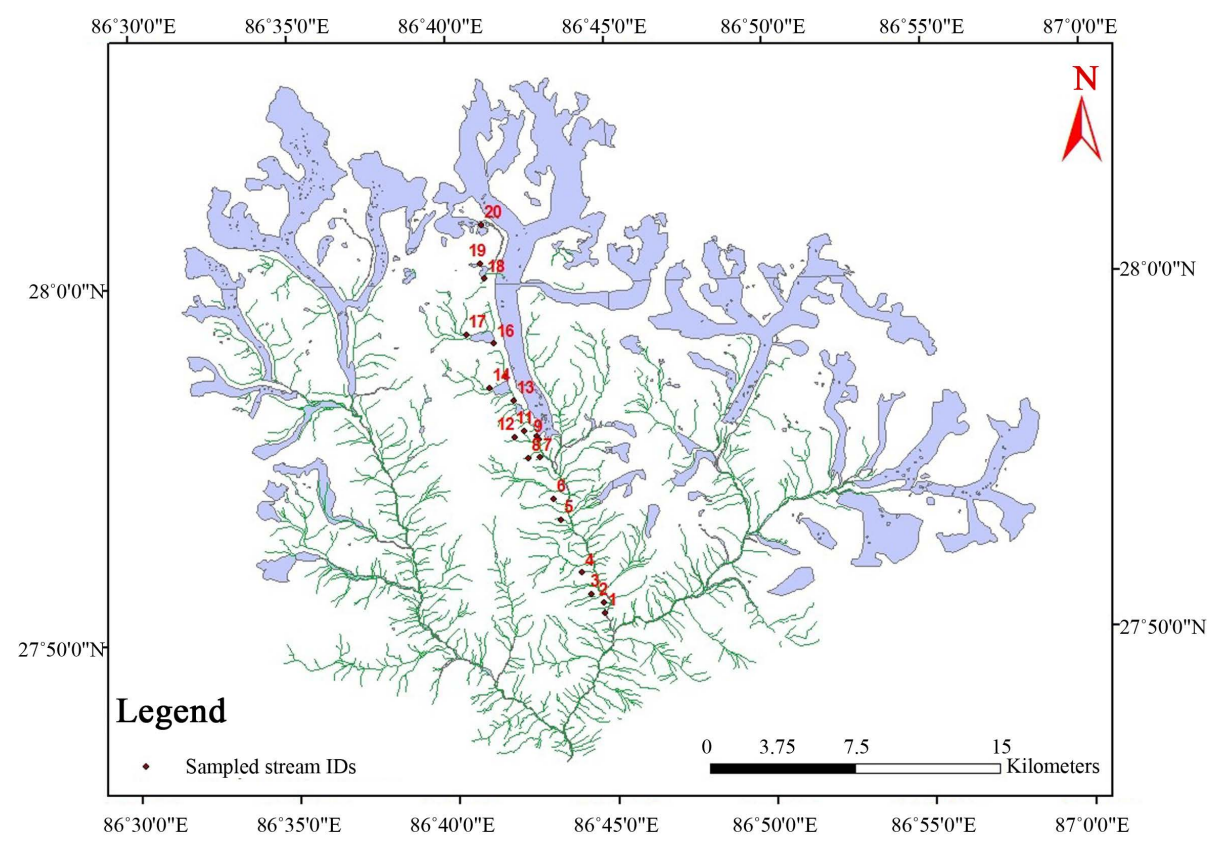

Figure 2. Sampling stations. 
so as to examine whether there is any relationship of these parameters with elevation gradient. Sampling points 1 to 8 consist of first order streams which are devoid of lakes. Nevertheless, sampling points 9 to 15 are streams between Gokyo lake series. Sampling points 16, 17, 18, 19 and 20 are strictly located in lakes. Sampling points 16 and 17 are outlet and inlet of Lake 4 respectively. Similarly sampling points 18 and 19 are outlet and inlet of Lake 5 respectively. However, the sampling point 20 lies in Lake 6. The numbering of these streams is presented in Figure 2.

The average concentration of calcium ion in the sampling site is found to be $3.25 \mathrm{mg} / \mathrm{L}$ with standard deviation of 2.02, statistically as $3.25( \pm 2.02)$. Similarly, the average concentration of magnesium ion in $\mathrm{mg} / \mathrm{L}$ with standard deviation is $0.64( \pm 0.47)$. The average concentration of total silica and sulphate in $\mathrm{mg} / \mathrm{L}$ is $0.36( \pm 0.17)$ and 207.20 ( \pm 423.01$)$ respectively. Owing to extremely high variability of result in the data sets of sulphate ion due to high concentration in four sites for which geometric mean has been calculated and is 15.16 which is more representative. The statistical results of four parameters that are analysed have been presented in Table 1 .

Figures 3-6 demonstrate the concentration levels of analyzed four parameters of stream and lake waters in Gokyo region. The concentration of calcium (3.25 \pm 2.02$)$ is low compared to the former studies done in Everest region in 1995 and 1998 [6] [11] however, it is very low compared to the study done in 2010 [5]. In similar way,

Table 1. Mean concentration of selected parameters.

\begin{tabular}{cccccc}
\hline Parameters (mg/L) & Mean & Min & Max & Std. Dev & Geomean \\
\hline $\mathbf{C a}^{2+}$ & 3.25 & 0.56 & 7.94 & 2.02 & \\
$\mathbf{M g}^{2+}$ & 0.64 & 0.14 & 2.14 & 0.47 & \\
Total silica & 0.36 & 0.13 & 0.92 & 0.17 & 15.16 \\
$\mathbf{S O}_{4}^{2-}$ & 207.2 & 1.46 & 1291 & 423.01 & \\
\hline
\end{tabular}

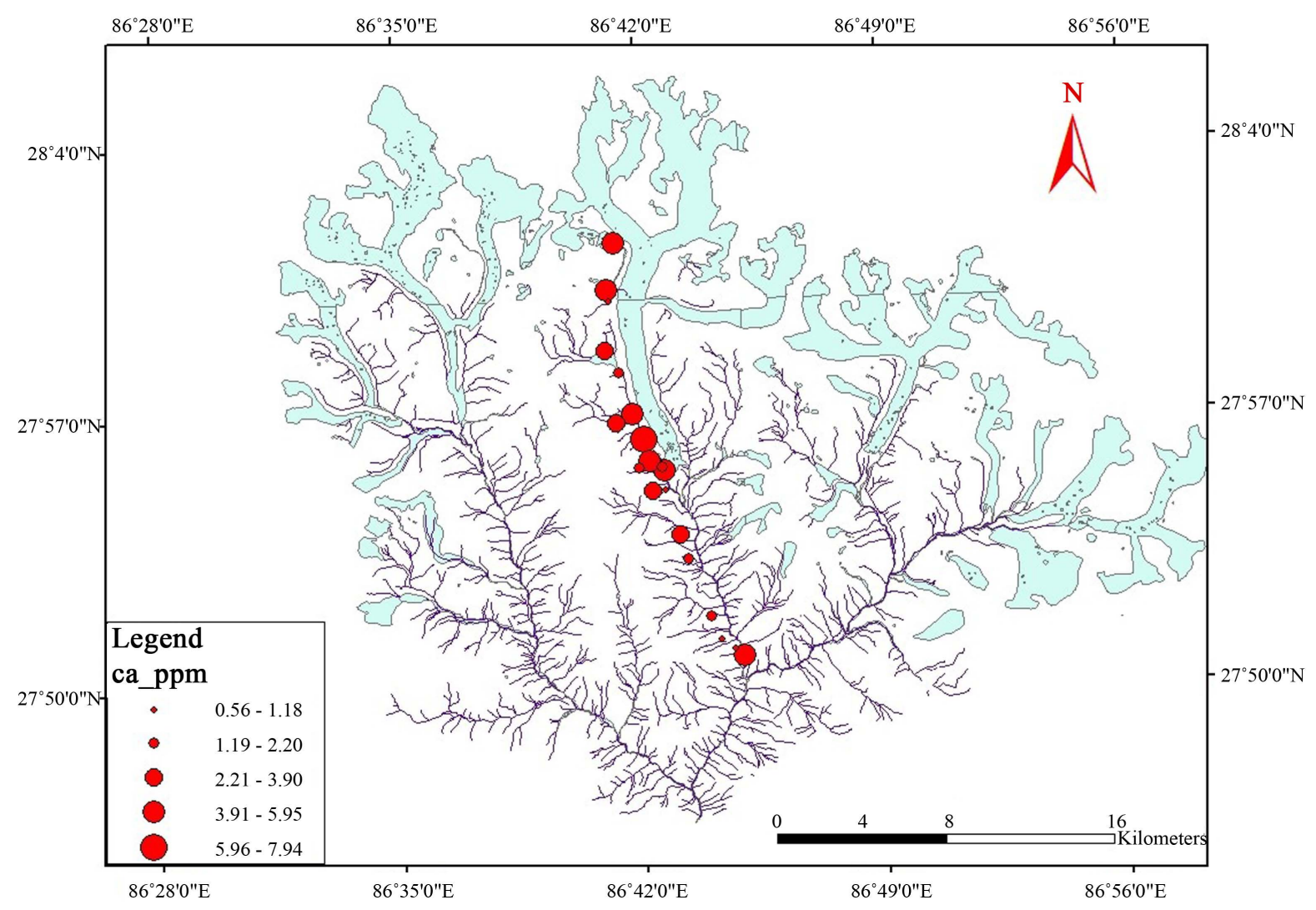

Figure 3. Calcium ion concentration. 


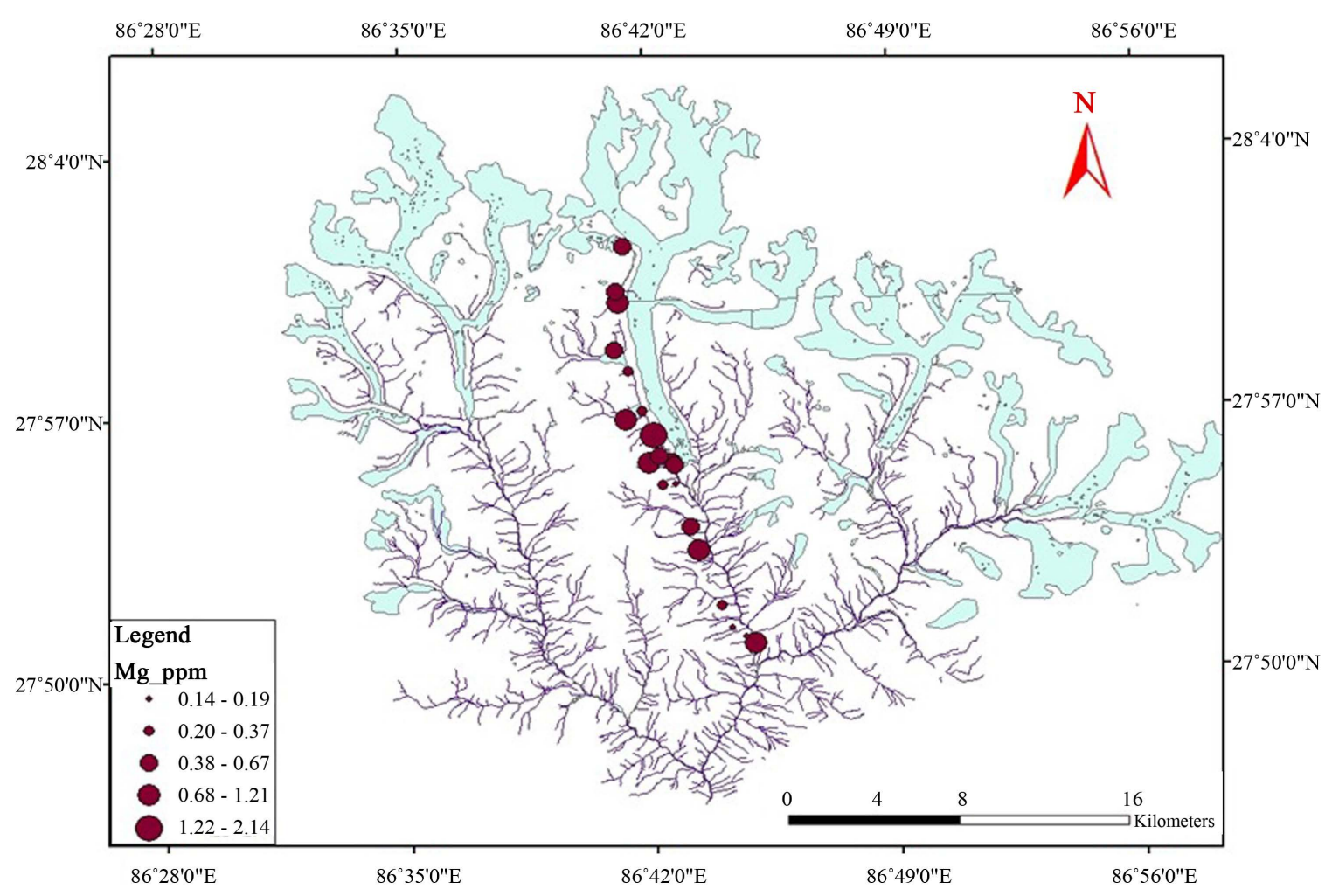

Figure 4. Magnessium ion concentration.

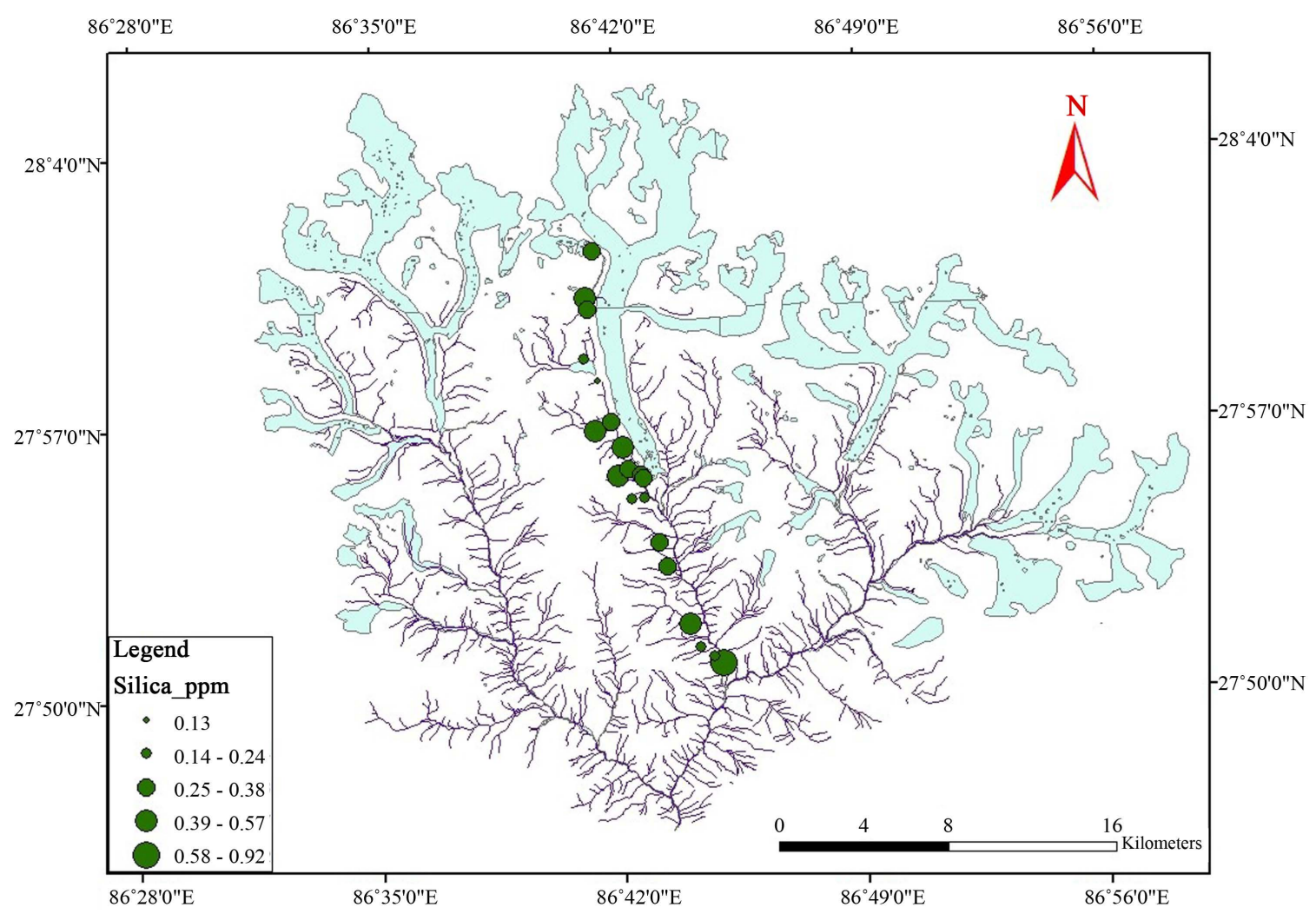

Figure 5. Silica ion concentration. 


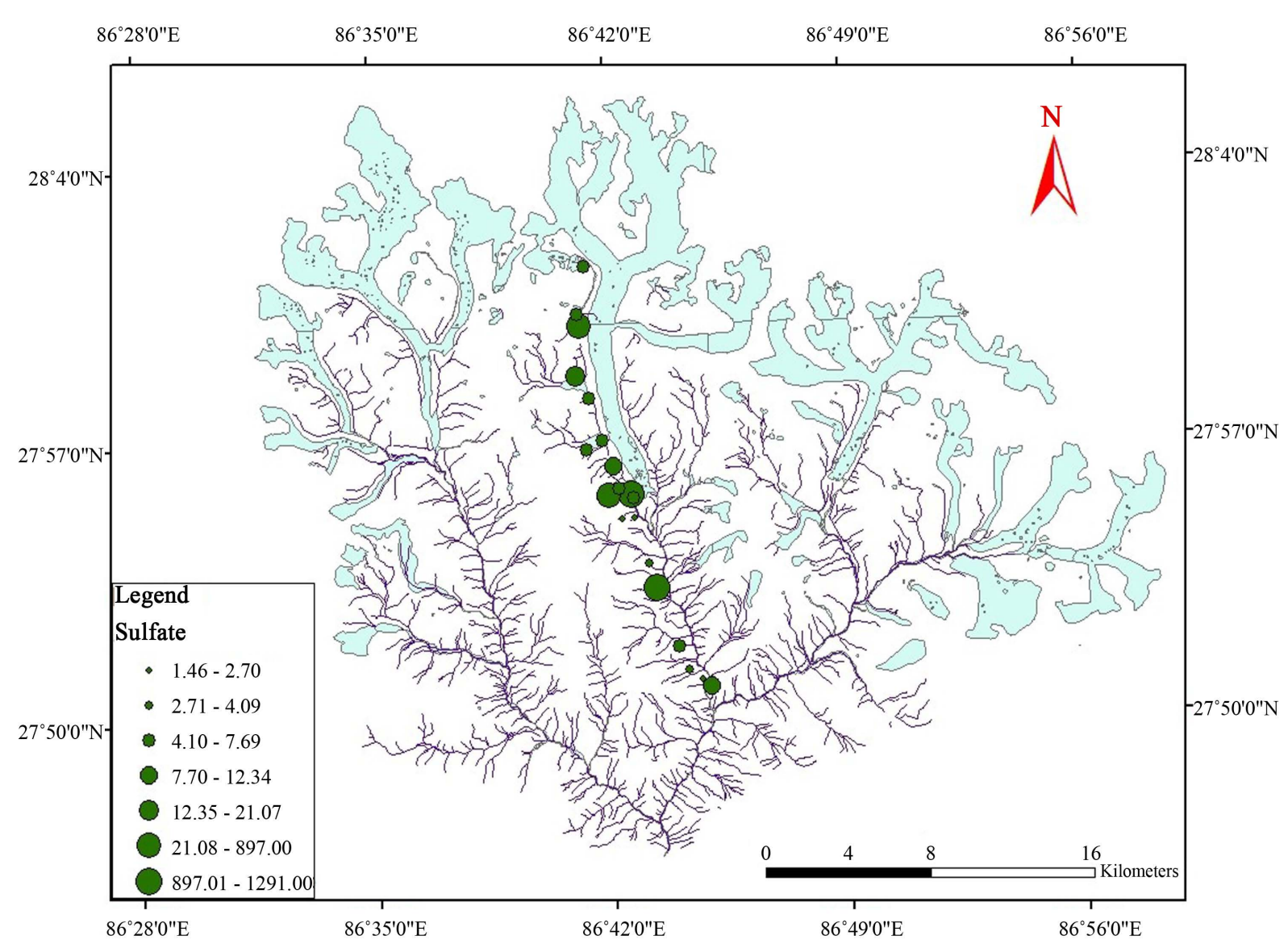

Figure 6. Sulphate ion concentration.

concentration of magnesium $(0.64 \pm 0.47)$ and total silica $(0.36 \pm 0.17)$ is also low compared to the results of study performed in 1995 and 1998 [6] [11]. However the total silica concentration is approximately similar to the study performed in 2010 [5]. Nevertheless, the sulphate concentration of this study is highly variable and very high compared to the previous studies [6] [11].

This study was done only in one season (3rd week, May 2013) during the dry period with low atmospheric inputs and low stream flows so that the major source of ions and silica to these streams and lakes is from chemical weathering. In the absence of significant atmospheric inputs of acid pollutants, the supply of acid protons required for weathering reactions in alpine glacial environments depends mainly on the dissolution of $\mathrm{CO}_{2}$ and oxidation of pyrite, the processes which accounts for the dominance of $\mathrm{HCO}_{3}^{-}$and $\mathrm{SO}_{4}^{2-}$ amongst anions solution [12]. And the readily weatherable source of $\mathrm{Ca}^{2+}$ and $\mathrm{Mg}^{2+}$ are alumino-silicates with carbonates that are easily identified in a number of geological formations in these regions [11].

The final objective of this study was to determine whether the ions concentration is related to the elevation gradient or not. For this, scatter chart of elevation withthe concentration of calcium, magnesium and total silica were plotted as shown in Figures 7-9 respectively.

The Pearson product-moment correlation coefficient was calculated using Microsoft, Excel Workbook for four parameters as mentioned above. Owing to extremely high variability of sulphate concentration the chart is not constructed. The Pearson Product-moment Correlation Coefficients for elevation gradient and concentration of calcium, magnesium, total silica and sulphate are $+0.350,+0.145,-0.275$ and +0.101 respectively. All the values showed very weak relationship between elevation gradient and ions concentration for Gokyo region. Hence, this study derives the finding that the ions concentrations in Gokyo region are not strictly correlated to eleva-tion gradient. Nevertheless, these are related tothe weathering phenomena, glacier and watershed characteristics and snow cover dynamics [1]. 


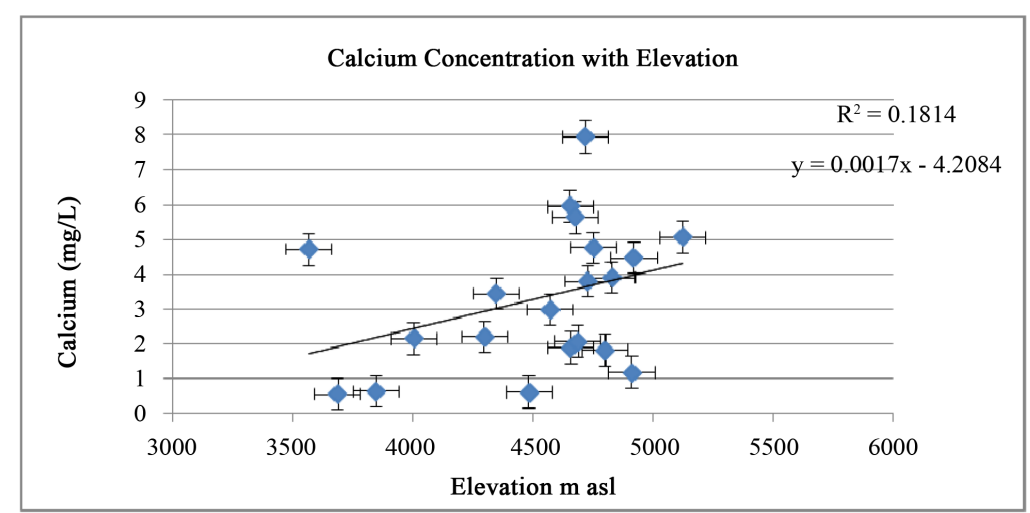

Figure 7. Scatter chart of calcium concentration.

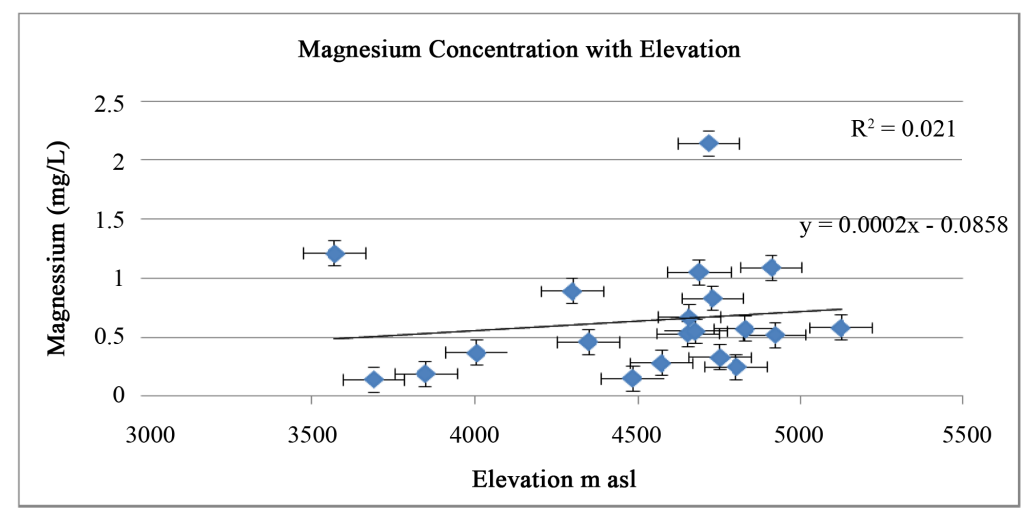

Figure 8. Scatter chart of magnessium concentration.

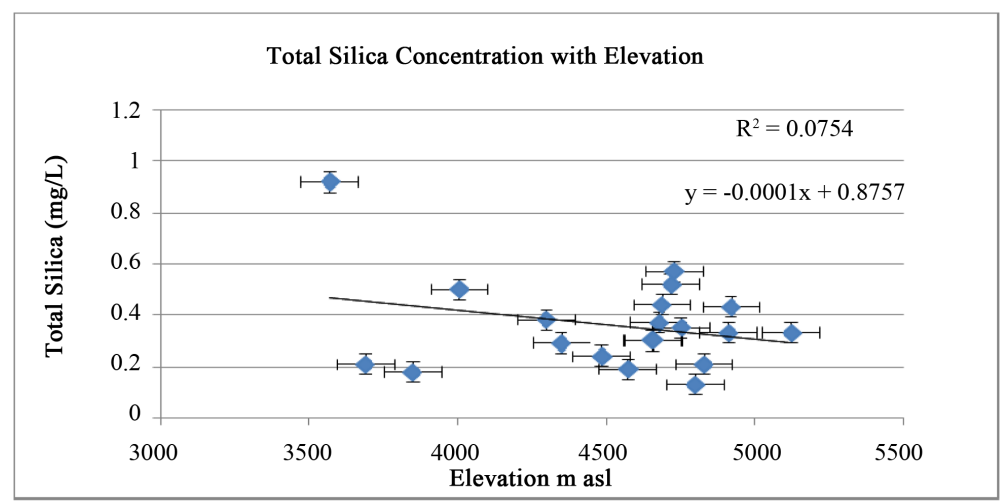

Figure 9. Scatter chart of total silica concentration.

\section{Conclusion}

The low concentration of calcium and magnesium ions in average compared to past studies was usual in the study site. However, the quantitative presence of total silica has been seen similar in temporal studies. Nevertheless, highly fluctuating concentration of sulphate ions could not be well explained and future studies are suggested. Pearson Product-moment Correlation Coefficient for elevation gradient and concentration of these four parameters showed very weak relationship which proves their disassociation.

\section{Acknowledgements}

We are very grateful to The Glacier Trust, UK for their financial assistance under Climate Change Education 
Project in Nepal supporting this research work. We are also thankful to the Department of National Park and Wildlife Conservation, Government of Nepal, and villagers in Gokyo Valley for their kind cooperation while conducting this research.

\section{References}

[1] Tartari, G.A., Tartari, G. and Mosello, R. (1998) Water Chemistry of High Altitude Lakes in the Khumbu and Imja Kola Valleys (Nepalese Himalayas). Memorie dell'lstituto Italiano di Idrolnologia, 57, 51-76.

[2] Löffler, H. (1969) High Altitude Lakes in Mt Everest Region. Verhandlungen Internationale Vereinigung Limnologie, 17, 373-385.

[3] Bhuju, D.R., Sharma, S., Jha, P.K. and Gaire, N.P. (2012) Scientific Discourse of Lakes in Nepal. Nepal Journal of Science and Technology, 13, 147-158.

[4] Sharma, C.M., Sharma, S., Bajracharya, R.M., Gurung, S., Juttner, I., Kang, S., Zhang, Q. and Li, Q. (2012) First Results on Bathymetry and Limnology of High-Altitude Lakes in the Gokyo Valley, Sagarmatha (Everest) National Park, Nepal. Limnology, 13, 181-192. http://dx.doi.org/10.1007/s10201-011-0366-0

[5] Gurung, S. (2012) High Altitude Aquatic Biodiversity of Gokyo Lake Series in Sagarmatha National Park, Nepal. A Dissertation, Submitted for the Partial Fulfillment of the Requirements for the Doctoral Degree (Ph.D.) in Environmental Science. Central Library, Kathmandu University, Lalitpur.

[6] Reynolds, B., Jenkins, A., Chapman, P.J. and Wilkinson, J. (1998) Stream hydrochemistry of the Khumbu, Annapurna and Langtang Regions of Nepal. Ecovision World Monograph Series, 123-141.

[7] Battarbee, R.W. (2005) Mountain Lakes, Pristine or Polluted? Limnetica, 24, 1-8.

[8] Kallf, J. (2002) Limnology. Prentice Hall. Upper Saddle River.

[9] National Population and Housing Census 2011. Volume 02, NPHC 2011, Government of Nepal National Planning Commission Secretariat Central Bureau of Statistics Kathmandu, Nepal.

[10] APHA, AWWA and WEF (1998) Standard Methods for the Examination of Water and Wastewater. 20th Edition, American Public Health Association, Washington DC.

[11] Reynolds, B., Chapman, B.J., French, M.C., Jenkins, A. and Wheater, H.S. (1995) Major, Minor and Trace Element Chemistry of Surface Waters in the Everest region of Nepal. Proceedings of a Boulder Symposium, IAHS, Publication No. 228.

[12] Tratner, M., Brown, G., Raiswell, R., Sharp, M. and Gurnell, A. (1993) A Conceptual Model of Solute Acquisition by Alpine Glacial Meltwaters. Journal of Glaciology, 39, 573-581. 